\title{
8. Sınıf Matematik Ders Kitabının PISA Temel Matematik Beceri Seviyelerine Göre İncelenmesi ${ }^{1}$
}

Betül Şirin ${ }^{2}$

Avni Yıldız

\section{Öz}

Type/Tür:

Research/Araştırma

Received/Geliş Tarihi: January

16/ 16 Ocak 2020

Accepted/Kabul Tarihi:

November 10/ 10 Kasim 2020

Page numbers/Sayfa No: 1158-

1176

Corresponding

Author/İletisimden Sorumlu

Yazar: yildiz.avni@gmail.com

\section{$\checkmark$ iThenticate ${ }^{\circ}$}

This paper was checked for plagiarism using iThenticate during the preview process and before publication. / Bu çalışma ön inceleme sürecinde ve yayımlanmadan önce iThenticate yazılımı ile taranmıştır.

Copyright (C) 2017 by

Cumhuriyet University, Faculty of Education. All rights reserved.
Ülkemizde yapılan çalışmalara göz atıldı̆̆ında ders kitapları üzerine öğretmen ve öğrenci görüşlerinin yanı sıra velilerin de ders kitapları üzerine görüşlerinin alındığı görülmektedir. Bu araştırmanın amacı ise, Uluslararası Öğrenci Değerlendirme Programı (PISA) temel matematik beceri (iletişim, strateji, temsil, sembol, muhakeme, matematikleştirme) seviyelerine göre dağılımları, kullanımda olan 8. sınıf matematik ders kitaplarından birindeki sorular üzerinde incelemektir. Araştırmada doküman incelemesi yöntemi kullanılmıştır. Soruların incelenmesi için kitap, içerik ve ölçme - değerlendirme şeklinde iki bölüme ayrılmıştır. Doküman incelemesine tabi tutulan kaynak, 2017-2018 öğretim yılında kullanılan Milli Eğitim Bakanlığı 8. sınıf matematik ders kitaplarından biridir. Her bir beceri $0^{\prime}$ dan 3 . seviyeye kadar gruplandırılmıştır. Yapılan analizlerin ardından bulgular 5 öğrenme alanı altında tabloya dökülmüştür ve her bir becerinin seviyelerdeki dağılım yüzdeleri verilmiştir. Araştırma sonucunda genel olarak öğrenme alanlarında, incelenen 6 beceride de alt seviyelerdeki sorulara kitapta daha çok yer verildiği görülmüştür. Özellikle alt seviyedeki soruların olasılık öğrenme alanında baskın olarak yer aldığı görülmüştür. Elde edilen sonuçlar doğrultusunda araştırmacılara "PISA temel matematik becerilerini beş öğrenme alanına nasıl yerleştirmeliyiz? ve " $\mathrm{Bu}$ beceriler öğrenme alanlarına göre nasıl farklılaşmalı?" problemlerini çalışmaları önerilmektedir.

Anahtar Kelimeler: PISA, 8. sinıf matematik ders kitabı, matematiksel beceriler, öğrenme alanları, doküman incelemesi.

Suggested APA Citation/Önerilen APA Atıf Biçimi:

Şirin, B., \& Yildız, A. (2020). 8. sınıf matematik ders kitabının PISA temel matematik beceri seviyelerine göre incelenmesi. Cumhuriyet International Journal of Education, 9(4), 1158-1176. http://dx.doi.org/10.30703/cije.676100

${ }^{1} \mathrm{Bu}$ çalışma, birinci yazarın ikinci yazar danışmanlığında yaptı̆̆ı “Ortaokul 7. ve 8. Sınıf Matematik Ders Kitaplarının PISA Temel Matematik Beceri Seviyelerine Göre İncelenmesi” başlıklı yüksek lisans tezinin bir bölümüdür.

2 Matematik Öğretmeni, Milli Eğitim Bakanlığı, Zonguldak/Türkiye

Mathematics Teacher, Ministry of National Education, Zonguldak/Türkiye

e-mail: sirinbtl_78@hotmail.com ORCID ID: orcid.org/0000-0003-0763-0251

${ }^{3}$ Doç. Dr., Zonguldak Bülent Ecevit Üniversitesi Ereğli Eğitim Fakültesi Matematik Eğitimi ABD, Ereğli/Zonguldak/Türkiye

Assoc. Prof. Dr., Zonguldak Bülent Ecevit University Eregli Faculty of Education the Department of Mathematics Education, Ereğli/Zonguldak/Türkiye e-mail: yildiz.avni@gmail.com ORCID ID: orcid.org/0000-0002-6428-188X 


\title{
The Investigate of $8^{\text {th }}$ Grade Mathematics Course Book According to PISA Basic Mathematics Skills Levels
}

\begin{abstract}
Looking through the studies in our country, it is seen that teachers' and students' opinions have been received regarding the course books and in addition to all these, parents' views have been received about course books. As for the aim of this research, it is to analyze the distributions of Programme for International Student Assessment (PISA) basic mathematical skills levels (communication, devising strategies, representation, using symbols, reasoning and argumentation, and mathematizing) on the questions in one of the prevailing $8^{\text {th }}$ Grade mathematics course books. Document review was used in this research. In order to analyze the questions, the course book was divided into two sections: content, assessment and evaluation. The resource which was subjected to document review is one of the Ministry of National Education $8^{\text {th }}$ grade mathematics course books which were used during 2017-2018 academic year. Each skill was categorized between the Level 0 and Level 3. After the analysis, findings were converted to table under five learning domains and level distribution percentages of each skill were stated there. As a result of the research, it was seen that low level questions of six skills, studied generally in learning domains, were included predominantly in the course book. It was realized that especially low level questions were dominant in possibility learning domain. In accordance with the results obtained, researchers are suggested to study for these problems: "How should we place PISA basic mathematical skills under five learning domains?" and "How should these skills differentiate according to learning domains?".
\end{abstract}

Keywords: PISA, $8^{\text {th }}$ grade mathematics course books, mathematical skills, learning domains, document review.

\section{Giriş}

Bilgi çağındaki ülkeler, geleceğin bireylerini daha verimli yetiştirme çabası içerisindedir (Gürbüz, 2014). Ancak nitelikli ve başarılı bireylerin yetiştirilmesi eğitim ile sağlanabilir. Hızla gelişen bu bilgi çağında eğitimde başarıyı artırmak ve eğitim sisteminde yapılan yenilik ve reformların öğrenci üzerindeki etkilerini de görebilmek için yurt içinde farklı sınıf seviyelerinde ve ders alanlarında ölçme ve değerlendirme sınavlarına yer verilmektedir (Yılmaz, 2006).

Uygulanan sınavlar içerisinde Uluslararası Öğrenci Değerlendirme Programı (PISA) olan bir sınav da yer almaktadır. Bu sınav Ekonomik İşbirliği ve Kalkınma Örgütü (OECD) tarafından geliştirilmiş bir sınav olup, uluslararası ölçekte yapılan bir izleme çalışmasıdır (MEB, 2018a). Uluslararası ölçekte yapılan PISA'nın temel amacı ise 15 yaş grubu öğrencilerin okulda edindikleri bilgi ve becerileri günlük yaşamda kullanma becerilerini değerlendirmektir (MEB, 2018a). PISA sinavı, ilk olarak 2000 yılında yapılmış ve üçer yılda bir yapılmakta olan bu sınava Türkiye ilk defa 2003 yılında katılmıştır. PISA 2018 uygulaması, 37'si OECD üyesi olmak üzere 79 ülkeden yarım milyondan fazla öğrencinin katılımıyla gerçekleştirilmiştir (MEB, 2018a). PISA, öğrencileri farklı alanlarda değerlendirmektedir. Bunlar okuma becerileri, fen ve matematik alanlarından oluşmaktadır. Her üç yılda bir düzenli olarak uygulanan bu sınavda bir alan ön plana alınmaktadır. Örneğin PISA 2012 uygulamasında matematik alanı üzerinde değerlendirme yapılmıştır. 2003-2012 yılları arasında Türkiye' nin matematikteki düzeylerine bakıldığında düzey 1 ve bu düzey altındaki öğrenci oranı \%27,7'den \%15,5'e düşmüştür. Ancak bu oran, hâlâ 
OECD ortalamasındaki düzey 1 ve altındaki öğrenci oranının yaklaşık 1,5 katıdır (MEB, 2012). Bu yapilan sinavlar sonucunda ve elde edilen raporlardaki bu bilgiler üzerine henüz ülkemizde matematikte istenilen başarının elde edilemediği söylenebilir. Bu sonuçların da etkisiyle son zamanlarda eğitime, matematiğe ve matematik eğitimine karşı düşüncelerde önemli farklılıklar olmuştur (Soytürk, 2011). Çünkü düşünmeyi geliştirdiği için matematik, eğitimin önemli bileşenlerinden biridir (Umay, 2003). Matematik eğitiminde sadece matematiği bilen değil, karşılaşılan problemleri çözebilen ve çözüm üretebilen, bildiklerini kullanabilen, iletişime geçebilen, matematik yapan, bunları yapmaktan zevk alan insanlar yetiştirmeyi amaç edinmenin olduğunu söyleyebiliriz. Bu yeni amaçlar değişimi zorunlu kılmaktadır (Olkun ve Toluk, 2003). Gereken değişimler doğrultusunda son yıllarda düzenlenen eğitim programlarına eklemeler yapıldığı da söylenebilir. $\mathrm{Bu}$ bağlamda ilkokul ve ortaokul matematik öğretim programının özel amaçları içerisine "Öğrenci; matematiksel okuryazarlık becerilerini geliştirebilecek ve etkin bir şekilde kullanabilecektir." maddeleri yer almıştır. (MEB, 2018b).

Ortaokul matematik dersi öğretim programına bakıldığında söz edilen beceriler; matematiksel kavramları günlük hayata geçirip kullanabilme yeteneği, problem çözebilme yeteneği, problem çözme süreci içerisinde akıl yürütme sürecini ve kendi düşüncelerini ifade edebilme yeteneği olarak sıralanabilir. Bununla birlikte matematiksel süreç becerilerini (iletişim, akıl yürütme, ilişkilendirme) ve matematik okuryazarlık becerisini kullanabilme becerilerine yer verilmiştir (MEB, 2013; MEB, 2018b). Programlar içerisinde bahsi geçen beceriler 1şı̆̆ında da PISA temel matematik becerilerinden birçoğunun öğretim programları içerisinde olduğu söylenebilir. Buna rağmen PISA matematik yeterlik ölçeğine göre yapılan incelemede düzey sinıflamasında beş ve altıncı düzeyde yer alan soruların matematik kitaplarımızda yer almadığı saptanmıştır (İskenderoğlu ve Baki, 2011). Öğretim ortamlarında ortak olarak kullanılan ders kitaplarında bazı temel matematiksel becerilere yer verilmesi ve bu becerilerin kazandırılması, geliştirilmesi yönünde çalışmalar neticesinde matematik eğitiminde olumlu sonuçlar alınabilir. Bu bilgiler doğrultusunda eğitim öğretim ortamlarında müfredat kapsamında konuların işlenmesinde rehber görevini üstlenen ders kitaplarının öneminden söz edilebilir. Ders kitapları sınıf içerisinde öğretmenin kullandığı en temel kaynak olmasının yanı sıra öğrencilerin sürekli yanında bulabileceği, ders tekrarı ve değerlendirme etkinliklerini yapmalarına imkân veren araç gereçlerdir (Şaban, 2019). Tüm bunların neticesinde ders kitaplarının öğrenme ortamındaki önemli gücünü görmüş oluruz.

Ülkemizde yapılan çalışmalara göz atıldığında ders kitapları üzerine öğretmen görüşlerinin alındığı (Arslan ve Özpınar, 2009a; Çakır, 2006; Güder ve Tutak, 2012), öğretmen ve öğrenci görüşlerinin alındığı (Seven, 2001) ve öğretmenöğrenci görüşünün yanında velilerin de ders kitapları üzerine görüşlerinin alındığı (Özsoy, 2007) görülmektedir. Örneğin Arslan ve Özpınar (2009a) öğretmen görüşlerini aldıkları çalışmalarında elde ettikleri görüşlerden biri değerlendirme sorularının uygulama basamağından ileriye gitmediği şeklindedir. Başka çalışmalarda ders kitaplarının incelenmesi ve değerlendirilmesi (Dane, Doğar ve Balk1, 2004; Dede ve Yaman, 2005), programlara uygunluğu (Arslan ve Özpınar, 2009b, Şişman ve Akkaya, 2017) ve teknolojiye uygunluğunun değerlendirilmesi (Sevimli ve Kul, 2015) gibi çalışmalara da rastlanmıştır. Bunların yanında ders 
kitabındaki soruların PISA matematik yeterlilik düzeylerine göre incelendiği bir çalışma da yer almaktadır (İskenderoğlu ve Baki, 2011).

Ortaokul matematik dersi 5. - 8. sinıflar öğretim programinda bahsedilen beceriler; problem çözme, matematiksel süreç becerileri (iletişim, akıl yürütme, ilişkilendirme), duyuşsal beceriler, psikomotor beceriler, bilgi ve iletişim teknolojilerini (BIT) kullanabilme şeklinde yer almıştır (MEB 2013). Ayrıca matematik okuryazarlık becerisini etkin şekilde kullanabilme, matematiksel kavramları günlük hayatta kullanabilme, problem çözme sürecinde kendi düşüncelerini ve akıl yürütme sürecini ifade edebilme gibi beceriler de yenilenen öğretim programlarında yer almış bulunmaktadır (MEB 2018b). PISA sınavlarının da genel manada öğrencilerin herhangi bir durumda gerçek hayatta karşılaştıkları problemleri çözebilmek için okulda öğrendikleri bilgi ve becerileri ne kadar kullanabildiklerini değerlendirme amaçlı yapıldığı söylenebilir. Yani öğretim programımızdaki beceriler, PISA matematik alanındaki başarı için de gerekmektedir denilebilir. Fakat PISA'daki matematik sorularında istenilen başarının elde edilebilmesi için öğrencilerin becerilerinin geliştirilmesinin yanında PISA matematik alanı üzerine yayınlanan sınav raporlarının sonuç ve değerlendirmeleri üzerinden de kitapların incelenmesi önemlidir. $\mathrm{Bu}$ maksatla ders kitaplarının temel matematiksel beceriler açısından incelenmesinin faydalı olacağı düşünülebilir. Araştırmada PISA temel matematik becerileri olarak; iletişim, strateji, temsil, sembol, muhakeme, matematikleştirme şeklinde 6 beceri ifade edilmiştir (Turner, Blum ve Niss, 2015). Diğer taraftan 8. sınıf öğretim programlarında yer alan konu içeriklerinde cebirsel ifadelere, denklem çözümlerine, aşamalı olarak problem çözümlerine ve birden fazla temsil biçimlerine yer verilmesi nedeniyle PISA temel matematik becerilerini daha fazla kapsayacağ1 düşünüldüğü için 8 . sinıf ders kitabının doküman analizine tabi tutulmasına karar verilmiştir. Bunun yanında Ekonomik İşbirliği ve Kalkınma Örgütü (OECD) tarafından uygulanan bu sınavın 15 yaş grubu öğrencilere yapıldığı bilinmektedir. Bu sebeple de yaş aralığına daha uygun olacağı düşünülen 8. sınıf ders kitabı seçilmiştir. Böylece çalışmanın amacı, PISA temel matematik beceri (iletişim, strateji, temsil, sembol, muhakeme, matematikleştirme) seviyelerine göre dağılımları, kullanımda olan 8. sınıf matematik ders kitaplarından birindeki her bir öğrenme alanındaki sorular üzerinde ayrı ayrı incelemektir. Araştırmanın, okullarda etkin olarak kullanılan matematik ders kitaplarını geliştirme açısından önemli olduğu söylenebilir.

\section{Araştırmanın Modeli}

\section{Yöntem}

Ders kitabının teker teker okunması ve derinlemesine inceleme ve yorumlanmasını amaçlayan bu araştırma için nitel araştırma yönteminin uygun olacağına karar verilmiş bu nedenle de doküman incelemesi araştırmanın modeli olarak kullanılmıştır.

\section{Veri Toplama Araçları ve Analizi}

Araştırma içerisinde 8. sınıf matematik ders kitabındaki örnek sorular, alıştırma ve ünite değerlendirme bölümlerindeki sorular, PISA temel matematiksel beceriler açısından doküman analizi ile ayrıntılı incelenmiştir. Bu bağlamda doküman 
analizinde kullanılan kaynak, Milli Eğitim Bakanlığının 2017-2018 eğitim öğretim yılı içinde hizmette olan herhangi bir ilköğretim matematik ders kitaplarından biridir. Bu kitap özel bir yayın evi tarafından yayınlanmış olup Millî Eğitim Bakanlığı kararıyla basım yılından itibaren beş yıl süre ile ders kitabı olarak uygun görülmüştür.

Ders kitabı içerisinde verilen örnek sorular içerik bölümünde, alıştırma ve ünite sonu değerlendirme soruları ise ölçme ve değerlendirme bölümleri başlığ1 altında incelenmiştir. Yapılan analizlerin ardından bulgular 5 öğrenme alanı altında tabloya dökülmüştür ve her bir becerinin seviyelerdeki dağılım yüzdeleri tablolarda sunulmuştur. Analizler yapılırken Turner, Blum ve Niss (2015) tarafından belirlenen yeterlik seviyeleri kullanılmıştır (Tablo 1). Beceriler iletişim, strateji, temsil, sembol, matematikleştirme ve muhakeme şeklindedir. PISA temel matematiksel becerilerinin her biri 0. ile 3. seviye arasında gruplanmış ve tanımlanmıştır (Turner, Blum ve Niss, 2015). Bulgular bu açıklamalar dikkate alınarak incelenmiştir.

Aşağıdaki tabloda araştırmada kullanılan Assessing Mathematical Literacy kitabında yer verilen 6 beceri ve bu becerilerin her seviyesinde öğrencilerden yapması beklenilen davranışlar açıklanmıştır (Turner, Blum ve Niss, 2015).

Tablo 1

PISA Temel Matematiksel Beceriler ve Becerilerin Seviye Açıklamalan

BECERILER

İLETIŞ̧IM BECERISII

STRATEJILERI

OLUŞTURMA BECERİII

\section{BECERİ SEVIYYELERI}

0: Soru içerisinde gerekli bilgilerin doğrudan verildiği, kısa cümleler ile ifade edilen genellikle tek bir kelime ile ifade edilen cümlelerdir.

1: Verilen soru metinlerinde kısa cümlelerden daha uzun karmaşık cümlelerin oluşmasıdır. Soru çözümünde ilgili olmayan bilgilerin de yer verildiği ve ilgili olan bilgilerin bulup ilişkilendirilmesidir.

2: Verilen soru içeriğinde kullanılan ifadelerin işlevlerini anlamak ve ilişkiyi kurabilmek için gerekli olan öğeleri seçer ve kullanabilir. Verilen çoklu öğeler içerisinde ilişki kurar. Ayrıca özet bir tanım yapabilme, hesaplama adımlarını yazması ve açılama yapmasını içerebilir.

3: Verilen soruda karışık ifadelerin farklı şekillerde iç içe geçmiş yapıları anlar ve soru içerisinde çözümde kullanılan öğeleri bulur, ayırır ve görevler arasında bağlantıyı kurabilir. Karmaşık ilişkilerin problemlerin çözümünde birleşenleri birleştirir ve argüman oluşturur.

0: Çözüm için gerekli olan adımların doğrudan belirgin olduğu yapilardir.

1: Verilen bilgileri kullanarak belli bir strateji ile çözüme gidilen tek aşamalı sorulardır.

2: Bu seviyede tek aşamadan ziyade birden fazla adımla çözülen stratejiler geliştirir.

3: $\mathrm{Bu}$ seviyelerde karmaşık bir strateji oluşturur, oluşturulan stratejileri çözüm sürecini takip eder ve oluşturulan stratejileri karşılaştırır ve değerlendirmesini yapar.

0: Verilen ifadeler matematiğe ait bir durumdur.

MATEMATIKKLEŞTİRME BECERİSİ
1: Verilen durumda varsayımlar, ilişkiler ve değişkenler ile bir model inşa edebilir. Matematiksel ifadelerden verilen durumun sonucunu doğrudan oluşturabilir. 
2: Verilen ifadelerde değişkenleri, sabitleri, ilişkileri kullanarak bir matematiksel model oluşturabilir. Ya da verilen bir durumda değişiklik yapabilir veya problem durumları içerisinde matematiksel ifadelerin sonuçlarını yorumlayabilir.

3: Verilen ifadelerde değişkenleri, sabitleri, ilişkileri kullanarak bir matematiksel model oluşturabilir. Ya da verilen bir durumda değişiklik yapabilir ya da problem durumları içerisinde matematiksel ifadelerin sonuçlarını yorumlayabilir. Bunların yanında oluşturulan modelleri onaylar ve değerlendirir. Ayrıca matematiksel ifadeleri oluşturan modelleri karşılaştırma ve ilişkilendirme yapabilir.

0: Basit bir temsilden değerleri okur.

1: Verilen durumlarda ilişkileri açıklayabilmek için basit veya standart bir temsil gösterimi kullanabilir. Grafikten değer okuyabilir, karşılaştırma yapabilir, tablolardan verileri elde edebilir.

TEMSIL/TASVİR BECERİsi $\quad$ 2: Verilen durum içinde karmaşık bir temsili anlar ve oluşturabilir.

3: Temsilleri karşılaştırma yapar, değerlendirebilir ve karmaşık verilen ifadeleri temsile dökebilir.

0: Matematikte basit aritmetik işlem içeren ifadeleri yapar. Örneğin iki kenar çarpımı ile bulunabilen dikdörtgenin alan hesabının yapabilmesidir.

1: Aritmetik işlemleri yapar fakat bunların yanında kesir ve ondalık işlemler de dahilindedir. Örneğin üçgenin iç açılarının toplamını bilindiğinde verilmeyen bir açıyı bulmak için gerekli olan işlemi yapar.

2: Verilen ifadelerde birçok değişken kullanabilir. Bilinen bir formülü kullanabilir ve yeniden inşa edebilir. Birçok formül ve kuralları birlikte kullanabilir ve seviye 1 'de gerçekleştirdiği tekrarlanan hesaplamaları kullanir.

3: Bir formül, kural veya tanımla çok adımlı bir işlem yapabilir ve değişkenleri içeren karmaşık ilişkiler üzerinde çalışma yapabilir. Bir durum için hangi cebirsel ifadenin daha uygun olduğuna karar verebilir.

0: Verilen ifadeden çıarımın doğrudan yapılmasıdır.

1: Çıkarım yapılabilmesi için gerekli adımların yapılması gerekir. Basit bilgilerin yer aldığı bir problemde muhakeme için yapılması gereken işlemleri yapar ve çıkarımları bulur.

MUHAKEME BECERISİ 2: Ayrı olarak verilen ifadelerin birleştirilmesi ve karmaşı ilişkilerin kurulup çıkarımların yapılmasıdır.

3: Birbiri ile bağlantılı olan çıarım zincirleri inşa eder. Oluşan çıkarımları kontrol edip değerlendirebilir ve sentezler.

Aşağıda bulgular kısmındaki analizlerin nasıl yapıldı̆̆ına örnek olması bağlamında 8. sınıf matematik ders kitabında sunulan örnek bir sorunun olası çözüm yollarından biri göz önünde bulundurularak temel matematiksel becerilerdeki seviyelerin açıklanmasına yer verilmiştir. 
Aşağıdaki karelerde verilen taralı böıgelerden hangisinin alanı, iki kare farkı kullanılarak bulunabilir?

A)
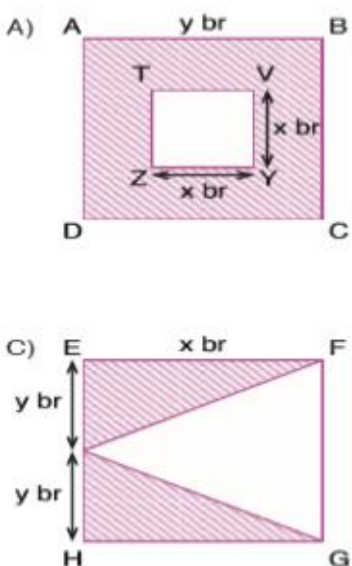

B)

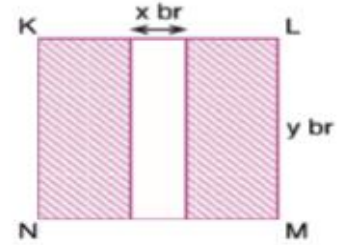

D)

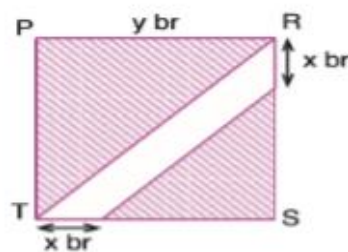

Şekil 1. Ders kitabı cebir öğrenme alanı, ölçme-değerlendirme sorusu

Soruda sonuçta varılması gereken, iki kare farkını veren ifadenin bulunması gerektiği doğrudan verilmiştir. $\mathrm{Bu}$ nedenle iletişim seviyesi 0. seviyeyi yansıtmaktadır. Strateji becerisi açısından incelendiğinde belirgin bir strateji uygulanacaktır. Bu şu anlama gelmektedir ki taralı bölgelerin alan formüllerini yazma ve bu alanları tüm geometrik şeklin alan formüllerinden çıkarma işlemi yapılması beklenilmektedir. Soru verilen ifadelerin kullanılması ve belirgin bir strateji içermesi nedeniyle 1 . seviyededir. Sembol becerisinde kenar uzunlukları verilen ifadelerden taralı bölgelerin alanlarının hesaplanmasının istenildiği söylenebilir. Örneğin A şıkkında ABCD karesinin alanını " $y \cdot y$ " yazması gerektiği gibidir. Bu sebeple sembol becerisi 0 . seviyededir. Modellerin yorumlanması veya çözülmesi için başka bir temsile gerek duyulmaması sebebi ile temsil becerisi 0 . seviyeyi yansıtmaktadır. Değişkenlerin kullanıldığını ve verilen modellerin problem durumunu dikkate alarak, taralı bölgenin alan formüllerinin ilişkisini çıkararak matematiksel sonuç yani iki kare farkı yorumunu çıkarmakta ve böylece matematikleştirme becerisinde 2. seviyeyi yansıtmaktadır. Problemde yer alan farklı alan formül parçacıklarının birleştirilmesi ve verilen alan formüllerindeki cebirsel ifadeleri ilişkilendirerek iki kare farkı özdeşliğinin yapılacağının sezinlenebilmesi nedeniyle muhakeme becerisinin 2 . seviyeyi yansıttığı yorumu yapılabilir.

Seviye düzeylerini belirlerken güvenirliği artırmak amaçlı farklı süreli zamanlarda tekrar inceleme yapılıp analizler karşılaştırılmış olup tutarlılık dikkate alınmıştır. Karşılaştırma sonucunda aynı düzeyi gösterdiği ifade edilenler aynen alınmış, farklı zamanlarda farklı yargıda bulunulan durumlar üzerinde danışman görüşleri alınmış ve ortak bir karar oluşturulmaya çalışılmıştır.

\section{Bulgular}

Ders kitabı, içerik ve ölçme - değerlendirme bölümleri başlı̆̆ı altında incelenmiştir. Veriler öğrenme alanlarına göre düzenlenip bir araya getirilmiştir. Becerilerin her biri için seviye dağılım çizelgeleri sırasıyla bu bölümde verilmiştir. 


\section{Sayılar ve İşlemler Öğrenme Alanına İlişkin Bulgular}

Sayılar ve işlemler öğrenme alanı içerisinde içerik bölümünde yer verilen 84 örnek soru ve ölçme - değerlendirme bölümünde yer verilen 170 soru incelenip seviye dağılımları aşağıdaki gibi Tablo 2' de açıklanmıştır.

Tablo 2

Sayılar ve İşlemler Öğrenme Alanına İlişkin Veriler

\begin{tabular}{|c|c|c|c|c|c|c|c|c|c|c|c|}
\hline \multirow[t]{2}{*}{ Beceriler } & \multirow[t]{2}{*}{ Bölümler } & \multicolumn{2}{|c|}{0} & \multicolumn{2}{|r|}{1} & \multicolumn{2}{|r|}{2} & \multicolumn{2}{|c|}{3} & \multicolumn{2}{|c|}{ Toplam } \\
\hline & & $\mathrm{N}$ & $\%$ & $\mathrm{~N}$ & $\%$ & $\mathrm{~N}$ & $\%$ & $\mathrm{~N}$ & $\%$ & $\mathrm{~N}$ & $\%$ \\
\hline \multirow[t]{3}{*}{ İletişim } & İçerik & 77 & 91.6 & 6 & 7.1 & 1 & 1.2 & - & - & 84 & 100 \\
\hline & Ölçme & 156 & 91.7 & 14 & 8.2 & - & - & - & - & 170 & 100 \\
\hline & Değerlendirme & & & & & & & & & & \\
\hline \multirow[t]{3}{*}{ Strateji } & İçerik & 39 & 46.4 & 15 & 17.8 & 30 & 35.7 & - & - & 84 & 100 \\
\hline & Ölçme & 53 & 31.1 & 54 & 31.7 & 63 & 37.05 & - & - & 170 & 100 \\
\hline & Değerlendirme & & & & & & & & & & \\
\hline \multirow[t]{3}{*}{ Matematikleştirme } & İçerik & 65 & 77.3 & 19 & 22.6 & - & - & - & - & 84 & 100 \\
\hline & Ölçme & 148 & 87 & 22 & 13 & - & - & - & - & 170 & 100 \\
\hline & Değerlendirme & & & & & & & & & & \\
\hline \multirow[t]{3}{*}{ Temsil } & İçerik & 83 & 98.8 & 1 & 1.1 & - & - & - & - & 84 & 100 \\
\hline & Ölçme & 169 & 98.8 & 1 & 1.1 & - & - & - & - & 170 & 100 \\
\hline & Değerlendirme & & & & & & & & & & \\
\hline \multirow[t]{2}{*}{ Sembol } & İçerik & 68 & 80.9 & 16 & 19.04 & - & - & - & - & 84 & 100 \\
\hline & Ölçme & 122 & 71.7 & 48 & 28.2 & - & - & - & - & 170 & 100 \\
\hline \multirow{3}{*}{ Muhakeme } & $\begin{array}{l}\text { Değerlendirme } \\
\text { İcerik }\end{array}$ & 68 & 80.9 & 16 & 19 & - & - & - & - & 84 & 100 \\
\hline & Ölçme & 145 & 85.2 & 25 & 14.7 & - & - & - & - & 170 & 100 \\
\hline & Değerlendirme & & & & & & & & & & \\
\hline
\end{tabular}

İletişim becerisine bakıldığında; içerik bölümünde 84 soruda \%91.6 gibi yüksek bir oranla 0 . seviye soruların yer aldığı görülmektedir. Bu durum içerik bölümüne çok yakın bir oranla (\%91.7) ölçme ve değerlendirme bölümünde de karşımıza çıkmaktadır. Bununla beraber 1. seviyeden sorulara 0. seviyedeki kadar yoğunluk verilmese de kitapta yer almıştır. Bununla birlikte 2. seviyeden sorulara içerik bölümünde birer tane de olsa yer verilirken, 3. seviyeden herhangi bir soruya her iki bölümde de yer verilmediği belirlenmiştir.

Strateji becerisinde seviye dağılım yüzdeleri incelendiğinde içerik ve ölçme değerlendirme bölümlerinde de 3 . seviye dışında her seviyeden soruya yer verilmiştir. İçerik bölümünde \%46.4 oranında 0. seviye ağırlık göstermiştir. Bu oranı \%35.7 oranıyla 2. seviye takip etmektedir. Ölçme - değerlendirme bölümünde ise ağırlıklı olarak \%37.05 oranla 2. seviye yoğunluk göstermiştir. Aynı zamanda \%31.1 oranında 0 . seviye soruların yer aldığı görülmüştür. Değerlendirme bölümünde 1 . seviyedeki sorular \%31.7 oranındayken, içerik bölümünde 1 . seviyenin \%17.8 oranıyla yer aldığ1 görülmüştür. Geriye kalan matematikleştirme, temsil, sembol, muhakeme becerilerinin her iki bölümde de yer alan sorularda ağırlıklı olarak 0 . seviye olduğu görülmektedir. Düşük bir oranla 1. seviye sorulara yer verilirken, 2. ve 3. seviye sorulara yer verilmemiştir. 


\section{Olasılık Öğrenme Alanına İlişkin Bulgular}

İçerik bölümünde yer verilen 13 örnek soru ve ölçme - değerlendirme bölümünde yer verilen 23 soru incelenip seviye dağılımları Tablo 3'te açılanmıştır.

Tablo 3

Olasılık Öğrenme Alanına İlişkin Veriler

\begin{tabular}{|c|c|c|c|c|c|c|c|c|c|c|c|}
\hline \multirow[t]{2}{*}{ Beceriler } & \multirow[t]{2}{*}{ Bölümler } & \multicolumn{2}{|l|}{0} & \multicolumn{2}{|l|}{1} & \multicolumn{2}{|l|}{2} & \multicolumn{2}{|l|}{3} & \multicolumn{2}{|c|}{ Toplam } \\
\hline & & $\mathrm{N}$ & $\%$ & $\mathrm{~N}$ & $\%$ & $\mathrm{~N}$ & $\%$ & $\mathrm{~N}$ & $\%$ & $\mathrm{~N}$ & $\%$ \\
\hline \multirow[t]{3}{*}{ İletişim } & İçerik & 7 & 53,84 & 6 & 46,15 & - & - & - & - & 13 & 100 \\
\hline & Ölçme & 19 & 82,60 & 4 & 17,39 & - & - & - & - & 23 & 100 \\
\hline & Değerlendirme & & & & & & & & & & \\
\hline \multirow[t]{3}{*}{ Strateji } & İçerik & 13 & 100 & - & - & - & - & - & - & 13 & 100 \\
\hline & Ölçme & 20 & 86,9 & 3 & 13,04 & - & - & - & - & 23 & 100 \\
\hline & Değerlendirme & & & & & & & & & & \\
\hline \multirow[t]{3}{*}{ Matematikleştirme } & İçerik & 13 & 100 & - & - & - & - & - & - & 13 & 100 \\
\hline & Ölçme & 18 & 78,26 & 5 & 21,73 & - & - & - & - & 23 & 100 \\
\hline & Değerlendirme & & & & & & & & & & \\
\hline \multirow{3}{*}{ Temsil } & Içerik & 13 & 100 & - & - & - & - & - & - & 13 & 100 \\
\hline & Ölçme & 23 & 100 & - & - & - & - & - & - & 23 & 100 \\
\hline & Değerlendirme & & & & & & & & & & \\
\hline \multirow[t]{3}{*}{ Sembol } & İçerik & 13 & 100 & - & - & - & - & - & - & 13 & 100 \\
\hline & Ölçme & 23 & 100 & - & - & - & - & - & - & 23 & 100 \\
\hline & Değerlendirme & & & & & & & & & & \\
\hline \multirow[t]{3}{*}{ Muhakeme } & İçerik & 13 & 100 & - & - & - & - & - & - & 13 & 100 \\
\hline & Ölçme & 23 & 100 & - & - & - & - & - & - & 23 & 100 \\
\hline & Değerlendirme & & & & & & & & & & \\
\hline
\end{tabular}

Olasılık öğrenme alanına ait yukarıdaki tablo incelendiğinde baskın olarak içerik ve ölçme - değerlendirme bölümlerinde yer alan soruların 0 . seviyede yer aldığı görülmektedir, fakat iletişimin içerik bölümünde azımsanmayacak bir oranda yani \% 46.15 ile 1. seviyeden soruların da yer aldığı belirlenmiştir. En çok dikkat çeken diğer bir durum temsil, sembol ve muhakeme becerilerinde her iki bölümde de 0 . seviye ile sınırlılık vardır. Strateji becerisi içerik bölümünde soruların hepsi 0 . seviyede hazırlanmıştır. Ölçme - değerlendirme bölümünde ise \%13.04 oranıyla 1. seviyedeki sorulara da yer verildiği görülmüştür. Benzeri bir dağılım matematikleştirme becerisinde de gerçekleşmiştir. İçerik bölümünde soruların tamamı 0. seviyede sınırlı kalırken, ölçme değerlendirmede $\% 78.26$ oran ile 0 . seviyede, \%21.73 oran ile de 1 . seviyede sorulara yer verildiği görülmüştür.

\section{Geometri ve Ölçme Öğrenme Alanına İlişkin Bulgular}

$\mathrm{Bu}$ öğrenme alanında içerik bölümünde yer verilen 88 soru ve bunun yanında ölçme değerlendirme bölümünde yer verilen 179 soru incelenip seviye dağılımları Tablo $4^{\prime}$ te verilmiştir. 
Tablo 4

Geometri ve Ölçme Öğrenme Alanına İlişkin Veriler

\begin{tabular}{|c|c|c|c|c|c|c|c|c|c|c|c|}
\hline \multirow[t]{2}{*}{ Beceriler } & \multirow[t]{2}{*}{ Bölümler } & \multicolumn{2}{|l|}{0} & \multicolumn{2}{|l|}{1} & \multicolumn{2}{|l|}{2} & \multicolumn{2}{|l|}{3} & \multicolumn{2}{|c|}{ Toplam } \\
\hline & & $\mathrm{N}$ & $\%$ & $\mathrm{~N}$ & $\%$ & $\mathrm{~N}$ & $\%$ & $\mathrm{~N}$ & $\%$ & $\mathrm{~N}$ & $\%$ \\
\hline \multirow[t]{3}{*}{ İletişim } & İçerik & 75 & 85.2 & 9 & 10.2 & 3 & 3.4 & 1 & 1.1 & 88 & 100 \\
\hline & Ölçme & 107 & 59.7 & 36 & 20.1 & 36 & 20.1 & - & - & 179 & 100 \\
\hline & Değerlendirme & & & & & & & & & & \\
\hline \multirow[t]{3}{*}{ Strateji } & İçerik & 38 & 43.1 & 16 & 18.1 & 32 & 36.3 & 2 & 2.2 & 88 & 100 \\
\hline & Ölçme & 104 & 58.1 & 7 & 3.9 & 68 & 37.9 & - & - & 179 & 100 \\
\hline & Değerlendirme & & & & & & & & & & \\
\hline \multirow{3}{*}{ Matematikleştirme } & Içerik & 58 & 65.9 & 28 & 31.8 & 2 & 2.2 & - & - & 88 & 100 \\
\hline & Ölçme & 113 & 63.1 & 66 & 36.8 & - & - & - & - & 179 & 100 \\
\hline & Değerlendirme & & & & & & & & & & \\
\hline \multirow{2}{*}{ Temsil } & & 16 & 005 & 2 & 11 & 15 & 83 & & & 170 & 100 \\
\hline & Değerlendirme & & & & & & & & & & \\
\hline \multirow{3}{*}{ Sembol } & İçerik & 76 & 86.3 & 9 & 10.2 & 3 & 3.4 & - & - & 88 & 100 \\
\hline & Ölçme & 166 & 92.7 & 13 & 7.2 & - & - & - & - & 179 & 100 \\
\hline & Değerlendirme & & & & & & & & & & \\
\hline \multirow{3}{*}{ Muhakeme } & İçerik & 32 & 36.3 & 36 & 40.9 & 20 & 22.7 & - & - & 88 & 100 \\
\hline & Ölçme & 28 & 15.6 & 66 & 36.8 & 85 & 47.4 & - & - & 179 & 100 \\
\hline & Değerler & & & & & & & & & & \\
\hline
\end{tabular}

Tablo 4'te iletişim ve strateji becerisi için içerik bölümünde her seviyede sorunun bulunduğu görülmektedir. Bunun yanında bu becerilerde 0 . seviyede sorulara her iki bölümde de ağırlıklı olarak yer verildiği dikkat çekmektedir. Yüzdelik oranlara bakıldığında iletişim becerisinin içerik bölümünde \% 85.2 oranı ile 0 . seviyede yoğunluk vardır. Bunun yanında \%10.2 oranında 1. seviye, \% 3.4 oranında 2. seviye ve \% 1.1 oranında 3. seviye sorulara yer verilmiştir. Ölçme ve değerlendirme bölümünde yüzdelik oranlar değişim göstermiştir. \%59.7 oranıla 0 . seviyedeki, \%20.1 oranıla 1. seviyedeki ve \%20.1 oranılla da 2 . seviyedeki sorulara yer verildiği görülmüştür. Bu bölümde 3. seviyeden bir soru görülmemiştir. Strateji becerisinin oranlarına bakıldığında ise içerik bölümünde \%43.1 oranında 0 . seviye, $\% 18.1$ oranında 1 . seviye, $\% 36.3$ oranında 2 . seviye ve $\% 2.2$ oraniyla da 3 . seviyeden soruya yer verilmiştir. Değerlendirme bölümüne bakıldığında 3. seviye haricinde diğer seviyelerden sorulara yer verilmiştir. Strateji becerisine genel olarak bakıldığında içerik ve ölçme değerlendirme bölümlerinde 2 . seviyenin 1 . seviyeye oranla daha yüksek oranda olduğu görülmektedir.

Matematikleştirme becerisinde seviye dağılım yüzdeliklerine bakıldığında her iki bölümde de yaklaşık bir dağılım gösterdiği belirlenmiştir. Temsil ve sembol becerisinde seviye 3'e yer verilmemişken, 1 . ve 2 . seviyede ise çok az soruya yer verildiği görülür. Her iki beceride ortalama $\% 90$ gibi yüksek bir oranla 0 . seviyenin ağırlıklı olduğu görülmektedir.

Muhakeme becerisine bakıldığında 3. seviye haricinde diğer seviyelere yer verilmiştir. İçerik bölümünde $\% 40.9$ oranıyla 1 . seviye ağırlıklı olarak bulunmaktadır. Ölçme değerlendirme bölümünde ise bu ağırlıklı dağılımı \%47.4 oranıyla 2. seviye göstermiştir. 


\section{Cebir Öğrenme Alanına İlişkin Bulgular}

Cebir öğrenme alanında içerik bölümünde yer verilen 80 soru ve ölçme değerlendirme bölümünde yer verilen 149 soru incelenmiş olup seviye dağılımları Tablo 5'te açıklanmıştır.

Tablo 5

Cebir Öğrenme Alanı İlişkin Veriler

\begin{tabular}{|c|c|c|c|c|c|c|c|c|c|c|c|}
\hline \multirow[t]{2}{*}{ Beceriler } & \multirow[t]{2}{*}{ Bölümler } & \multicolumn{2}{|l|}{0} & \multicolumn{2}{|l|}{1} & \multicolumn{2}{|l|}{2} & \multicolumn{2}{|l|}{3} & \multicolumn{2}{|c|}{ Toplam } \\
\hline & & $\mathrm{N}$ & $\%$ & $\mathrm{~N}$ & $\%$ & $\mathrm{~N}$ & $\%$ & $\mathrm{~N}$ & $\%$ & $\mathrm{~N}$ & $\%$ \\
\hline \multirow[t]{3}{*}{ İletişim } & İçerik & 67 & 83.7 & 11 & 13.7 & 2 & 2.5 & - & - & 80 & 100 \\
\hline & Ölçme & 122 & 81.8 & 25 & 16.7 & 2 & 1.3 & - & - & 149 & 100 \\
\hline & Değerlendirme & & & & & & & & & & \\
\hline \multirow[t]{3}{*}{ Strateji } & İçerik & 30 & 37.5 & 22 & 27.5 & 28 & 35 & - & - & 80 & 100 \\
\hline & Ölçme & 67 & 44.9 & 51 & 34.2 & 31 & 20.8 & - & - & 149 & 100 \\
\hline & Değerlendirme & & & & & & & & & & \\
\hline \multirow[t]{3}{*}{ Matematikleştirme } & İçerik & 37 & 46.2 & 43 & 53.7 & - & - & - & - & 80 & 100 \\
\hline & Ölçme & 80 & 53.6 & 68 & 45.6 & 1 & 0.6 & - & - & 149 & 100 \\
\hline & Değerlendirme & & & & & & & & & & \\
\hline \multirow[t]{3}{*}{ Temsil } & İçerik & 52 & 65 & 5 & 6.2 & 23 & 28.7 & - & - & 80 & 100 \\
\hline & Ölçme & 112 & 75.1 & 10 & 6.7 & 27 & 18.1 & - & - & 149 & 100 \\
\hline & Değerlendirme & & & & & & & & & & \\
\hline \multirow[t]{3}{*}{ Sembol } & İçerik & 52 & 65 & 26 & 32.5 & 2 & 2.5 & - & - & 80 & 100 \\
\hline & Ölçme & 98 & 65.7 & 41 & 27.5 & 10 & 6.7 & - & - & 149 & 100 \\
\hline & Değerlendirme & & & & & & & & & & \\
\hline \multirow[t]{3}{*}{ Muhakeme } & İçerik & 57 & 71.2 & 22 & 27.5 & 1 & 1.2 & - & - & 80 & 100 \\
\hline & Ölçme & 103 & 69.1 & 41 & 27.5 & 5 & 3.3 & - & - & 149 & 100 \\
\hline & Değerlendirme & & & & & & & & & & \\
\hline
\end{tabular}

İletişim becerisine bakıldığında; 3. seviye haricinde her seviyeden soruya yer verildiği görülmektedir. Fakat ağırlıklı olarak içerik ve değerlendirme bölümlerinde ortalama $\% 80$ oranında 0 . seviyedeki sorulara yer verilmiştir.

Temel matematiksel becerilerden strateji becerisinde ise her iki bölümde de 3. seviye dışında her seviyedeki sorulara yer verildiği görülmüştür. Fakat 0 . seviyedeki sorulara daha ağırlıklı yer verildiği tespit edilmiştir.

Matematikleştirme becerisinde içerik bölümünde $\% 53.7$ oranıla 1 . seviye ağırlıklıdır. Ölçme - değerlendirme bölümünde ise \%53.6 oranıla 0 . seviye ağırlık göstermiştir. Her iki bölümde de 3 . seviyeden soruların yer almadığı sadece ölçme ve değerlendirme bölümünde 2 . seviyeden 1 soruya yer verildiği görülmüştür.

Temsil becerisinde ağırlıkl olarak 0 . seviyeden sorulara yer verilmiştir. Bunun yanında 0 . seviyeden sonra ağırlı̆̆ın 2. seviyede olduğu görülür. Sembol ve muhakeme becerisinde 0 . seviyede yoğunluk olduğu dikkat çekerken bunun yanında 3. seviye dışında diğer seviyelere de kitapta yer verilmiştir. Diğer taraftan 2. seviyenin, 1. seviyeye oranla yüzdelik olarak daha az olduğu da Tablo 5'te görülmektedir.

\section{Veri Düzenleme, Değerlendirme ve Yorumlama Öğrenme Alanına İlişkin Bulgular}

Bu alanda içerik bölümünde yer verilen 9 soru ve ölçme - değerlendirme bölümünde yer verilen 17 soru incelenip seviye dağılımları Tablo 6 'da açıklanmıştır. 
Tablo 6

Veri Düzenleme, Değerlendirme ve Yorumlama Öğrenme Alanına İlişkin Veriler

\begin{tabular}{|c|c|c|c|c|c|c|c|c|c|c|c|}
\hline \multirow[t]{2}{*}{ Beceriler } & \multirow[t]{2}{*}{ Bölümler } & \multicolumn{2}{|l|}{0} & \multicolumn{2}{|l|}{1} & \multicolumn{2}{|l|}{2} & \multicolumn{2}{|l|}{3} & \multicolumn{2}{|c|}{ Toplam } \\
\hline & & $\mathrm{N}$ & $\%$ & $\mathrm{~N}$ & $\%$ & $\mathrm{~N}$ & $\%$ & $\mathrm{~N}$ & $\%$ & $\mathrm{~N}$ & $\%$ \\
\hline \multirow[t]{3}{*}{ İletişim } & İçerik & 4 & 44.44 & 5 & 55.55 & - & - & - & - & 9 & 100 \\
\hline & Ölçme & 8 & 47.05 & 7 & 41.17 & 2 & 11.76 & - & - & 17 & 100 \\
\hline & Değerlendirme & & & & & & & & & & \\
\hline \multirow[t]{3}{*}{ Strateji } & İçerik & 7 & 77.77 & - & - & 2 & 22.22 & - & - & 9 & 100 \\
\hline & Ölçme & 8 & 47.05 & 3 & 17.64 & 6 & 35.29 & - & - & 17 & 100 \\
\hline & Değerlendirme & & & & & & & & & & \\
\hline \multirow[t]{3}{*}{ Matematikleştirme } & İçerik & 6 & 66.66 & 3 & 33.33 & - & - & - & - & 9 & 100 \\
\hline & Ölçme & 3 & 17.64 & 14 & 82.35 & - & - & - & - & 17 & 100 \\
\hline & Değerlendirme & & & & & & & & & & \\
\hline \multirow[t]{3}{*}{ Temsil } & İçerik & - & - & - & - & 9 & 100 & - & - & 9 & 100 \\
\hline & Ölçme & - & - & 1 & 5.88 & 16 & 94.11 & - & - & 17 & 100 \\
\hline & $\begin{array}{l}\text { Değerlendirme } \\
\text { İcerik }\end{array}$ & & 5555 & 4 & 1444 & & & & & 0 & 100 \\
\hline \multirow{2}{*}{ Sembol } & Ölccme & 8 & 47.05 & 9 & 52.94 & - & - & ـ & ـ & 17 & 100 \\
\hline & Değerlendirme & & & & & & & & & & \\
\hline \multirow[t]{3}{*}{ Muhakeme } & İçerik & 9 & 100 & - & - & - & - & - & - & 9 & 100 \\
\hline & Ölçme & 6 & 35.29 & 8 & 47.05 & 3 & 17.64 & - & - & 17 & 100 \\
\hline & Değerlendirme & & & & & & & & & & \\
\hline
\end{tabular}

Tablo 6'daki yüzdelik oranlara bakıldığında 3. seviyeden sorulara hiç yer verilmediği görülmektedir. İletişim becerisinde dağılım 0 ve 1 . seviyelerde yer almaktadır. Bu oranlar içerik bölümünde 0 . seviyede $\% 44.44$ ve bununla birlikte 1 . seviyede \%55.55 oranları ile yer almaktadır. Ölçme-değerlendirme bölümlerinde \% 47.05 oranında 0 . seviye, \% 41.17 oranında 1 . seviye ve \%11.76 oranında 2 . seviyeden sorulara yer verilmiştir. Bu beceride içerik bölümünden farklı olarak 2. seviyeden sorulara da yer verildiği görülmektedir.

Strateji becerisinin içerik bölümündeki dağılımlara bakıldığında ise 0 . seviye için \%77.7 ve 2 . seviye için de $\% 22.2$ oranında olduğu, yani yoğunluğun 0 . seviyede yer aldığı görülmektedir. Ölçme ve değerlendirme bölümünde ise 2. seviyeye kadar her seviyeden sorulara yer verilmiş, fakat 3 . seviyeden soruya yer verilmemiştir. $\% 47.05$ ile 0 . seviyeye ağırlık verilmiş olsa da \%35.29 yüzdelik ile 2 . seviyenin bu oranı takip ettiği dikkat çekmektedir.

Matematikleştirme becerisinin içerik ve ölçme - değerlendirmede tersine bir yayılım olduğu görülmektedir. İçerik bölümünde \%66.66 oranıyla 0 . seviye ağırlıklı bir dağılım göstermiştir. Ölçme- değerlendirme bölümünde ise \%82.35 oranyla 1. seviye ağırlıklı bir dağılım göstermiştir.

Temsil becerisinde tablodaki dağılımlar incelendiğinde bölümlerden içerikte soruların hepsinin 2. seviyede yer aldığı görülmektedir. \% 94.11 oranıla ölçme ve değerlendirme bölümünde de seviye 2' de ağırlık vardır.

Sembol becerilerinde dağılımın 0 . ve 1 . seviyede yer aldığı görülürken, bunun yanında 2 . ve 3 . seviyeden soruların yer almadığ1 belirlenmiştir. İçerik bölümünde 0 . seviye $\% 55.55,1$. seviye $\% 44.44$ oranında yer almıştır. Ölçme değerlendirme bölümünde ise oranlar tersine dönmüş yani \%47.05 oraniyla 0 . seviye, \%52.94 oranında 1. seviye dağılım göstermiştir. 
Muhakeme becerisinin yüzdelik dağılımları incelendiğinde içerik bölümünde seviye dağılımın hepsi 0 . seviyededir. Bununla birlikte ölçme ve değerlendirme bölümünde yüzdelik dağılımlara bakıldığında \%35.29 oranında 0 . seviyede, \%47.05 oranında 1. seviyede, seviye 2'de \%17.64 oranında yüzdelik dağılımlar elde edilmiştir.

\section{Tartışma, Sonuç ve Öneriler}

Yapılan bu çalışmada bir 8. sınıf matematik ders kitabında yer alan sorular, içerik ve ölçme değerlendirme bölümleri altında her bir öğrenme alanı için ayrı ayrı incelenmiştir. Ele alınan sorular, PISA temel matematiksel becerisi olarak Turner, Blum ve Niss (2015) tarafından belirlenmiş 6 becerinin her birindeki 0 ile 3 arasında gruplandırılan seviye düzeyleri açıklamalarına göre incelenmiştir. $\mathrm{Bu}$ sayede öğrenme alanları bağlamında da bir resim çekilebilmiştir.

Olasılık öğrenme alanında 2. ve 3. seviyeden sorulara yer verilmediği görülmüştür. Oysaki olasılık konusu matematiğin amaçlarında yer alan, olasılığa dayalı düşünme becerisini, bağımsız yaratıcı düşünme becerisini geliştirmesi yönüyle önemli bir konudur (Gürbüz, 2007). Yapılan çalışmalarda öğrencilerin çoğunun olasılık kavramı hakkında bir yapılandırma oluşturmada ve olasılık olaylarına yönelik nedenleri belirlemede zorlandıkları belirtilmiştir (Memnun, 2008; Yıldız ve Baltacı, 2015; Yıldız ve Baltacı, 2016). Öğrencilerin yaşadıkları zorlukların azaltılması için onlara yaşantılar sunulmasının önemli olduğu söylenebilir. Okullarda ders kitabı içerisinde verilen bir örnek problem ile bile öğrencilerin anlamaları sağlanabilir. Diğer taraftan matematiksel muhakeme becerileri ile olasılıksal muhakeme becerilerini karşılaştırma yönünde yapılan bir çalışmada, öğrencilerin bu becerilerde orta seviyede olduklarını ve bu iki beceri arasında pozitif yönde yüksek bir ilişki olduğu söylenmiştir (Erdem, 2011). Bu çalışmaların sonuçlarından beslenerek muhakeme becerilerinin geliştirilmesi açısından olasılık konusunun önemli olduğu düşünülebilir. Başka bir çalışmada Memnun (2008) olasılık kavramların öğrenilmesinde yaşanılan zorluklardan birinin muhakeme etme becerisindeki yetersizlik olduğunu vurgulamıştır. Araştırmada, olasılık öğrenme alanında muhakeme becerisi açısından kitabın içerik kısmında ve ölçme değerlendirme kısmında yer alan sorularında ağırlığın yalnız 0. seviyede kaldığı göz önüne alındığında, öğrencilerde olasılık konusunda bu beceriyi geliştirme yönündeki adımın zayıf kaldı̆̆ı söylenebilir. Bu nedenle matematik kitaplarında öğrencilerin olasılık öğrenme alanında bu beceriyi geliştirebilmeleri için muhakeme becerisindeki üst seviye sorulara da yer verilmelidir.

Strateji becerisi açısından bakıldığında, öğrencilerin soruların çözümlerinde nasıl strateji geliştirdikleri üzerine birçok araştırma yapılmıştır. Yapılan bir araştırmada, Şener ve Bulut (2015) 8. sınıf öğrencilerinin matematik dersinde karşılaştıkları güçlükleri belirleme üzerine yürüttükleri çalışmalarında, öğrencilerin rutin problemlerde 'uygun stratejinin seçimi' ve 'stratejinin uygulanması' basamaklarında sorun yaşadıklarını belirlemiştir. Bu tarz çalışmalardan strateji becerisinin önemi görülmektedir. Bu olumsuz sonuçları ortadan kaldırabilmek için öğrencilerin doğru strateji belirleme ve bu maksatla farklı strateji kullanma becerilerini geliştirme amaçlı öğrenme ortamlarında yer alan ders kitapları sayesinde bazı stratejiler çözümlü örneklerle gösterilebilir ve değerlendirme kısımlarında farklı 
stratejilere uygun sorulara yer verilebilir. Nitekim Altun ve Arslan (2006) stratejileri öğretme amacı ile organize edilen öğrenme ortamlarının, bazı stratejilerin öğretiminde etkin olduğunu ve yapılan testlerde pozitif yönde bir gelişim olduğunu söylemiştir. Bu araştırmada da diğer matematiksel becerilere oranla strateji becerisinde, olasılık öğrenme alanında 0 . ve 1 . seviye, diğer öğrenme alanlarında genellikle $0 ., 1$. ve 2 . seviyelerde dağılım olduğu görülmektedir. Kitaplarda strateji becerisi için farklı seviyelerde çeşitli soruların yer alması, öğrenciler açısından olumlu bir durumdur.

İncikabı (2017) tablo, grafik ve gerçek yaşam temsillerine ders kitaplarında çok az yer verildiğini belirlemiştir. Araştırmacının elde ettiği sonuç, bu araştırmada yer alan ders kitabındaki sorularda, temsil becerisine ait seviye dağılımlarında ağırlıklı olarak alt seviyelere yer verilmesi ile tutarlılık göstermiştir. Kitapta genel olarak basit değerlerin temsilden okunmasına veya basit bir standart temsile aktarıma yer verildiği görülmüştür. Öğrencilerin temsil becerilerini geliştirmek amaçlı ilgili tablo, grafik ve gerçek yaşam temsillerini kullanacağı örneklere ders kitaplarında daha çok yer vermeliyiz. Bu yönüyle ders kitaplarında her öğrenme alanında temsil becerilerini geliştirici yönde farklı sorulara kitap içerisinde yer verilebilir.

PISA'daki soruların genellikle öğrencilerin okuduklarını anlama ve yorumlama, problem çözme, çıkarımda bulunma, yaratıcı düşünme gibi becerileri kullanma yeteneğini ölçtüğü vurgulanmıştır (Savran, 2004). Bu tür becerileri ölçmeye çalışan bir sınav için, yürütülen başka bir çalışmada 1. sınıf öğretmen adaylarının programa yakın sorularda zorlanmadıklarını fakat PISA kültüründeki gerçek hayata yönelik sorularda zorlandıkları görülmüştür (Saenz, 2009). Bu nedenle matematik bilgilerini etkin bir şekilde kullanabilmeleri için temel matematiksel becerilerinin geliştirilmesi gerektiği söylenebilir. Buna karşın araştırmada incelenen ders kitabında da bazı becerilerin geliştirilmesi için farklı becerilerde, farklı seviyelerden sorulara yer verilmesi gerektiği düşünülebilir. Fakat araştırmada incelenen kitapta bütün seviyelerden soruların yer almadığı dikkat çekmektedir. Oysaki öğrencilerin daha üst seviye becerilere sahip olabilmesi ve PISA sınavları gibi uluslararası sınavlarda başarılı olabilmeleri için eğitim öğretimde kullanılan ders kitaplarında çeşitli becerilerin bütün seviyelerini kapsayan sorulara yer verilmelidir.

Kitap öğrenme alanları ve 6 beceri seviye düzeyleri açısı dışında genel bir bakış açısı ile bakıldığında özellikle seviye düzeylerinde içerik ve ölçme değerlendirme bölümlerindeki soruların temel matematiksel becerilerde genel olarak 0. seviyede ve 1. seviyede yer aldığı görülmüsstür. İskenderoğlu ve Baki (2011) çalışmalarında PISA 2003 raporlarında da bahsedilen matematik yeterliliklerine göre 8. sınıf matematik ders kitapları içerisinde 2. seviyede soruların ağırlıklı olarak yer aldığı sonucuna varmışlardır. Bu çalışmanın sonuçlarının, seviye bakımından 8 . sınıf kitaplarında alt seviyeden sorulara daha çok ağırlık verilmesi yönüyle, bu araştırmayla benzerlik gösterdiği yorumu yapılabilir. Çünkü bahsedilen bu çalışmada 2. seviyeye ulaşmış öğrencilerden, doğrudan çıkarımda bulunabilmesi ve başka herhangi bir beceriye gerek olmayan durumları yapabilmesi beklenir. Yani öğrencilerin sadece tek bir gösterimi kullanabilmesi ve bunların yanında temel işlemleri yapabilmesi, formülleri kullanabilmesi yeterlidir. Bu nedenle bahsi geçen yukarıdaki çalışmada 2. seviye becerilerin, bu araştırmadaki kuramsal çerçevede alt 
seviyelere denk geldiği yorumu yapılabilir. Başka bir çalışmada İskenderoğlu, Erkan ve Serbest (2013), 2008-2013 yılları arasında yapılan SBS' de yer alan matematik sorularını, PISA matematik yeterlilik düzeylerine göre sınıflandırmıştır. Araştırmacılar SBS' de sorulan matematik sorularının her seviyeye uygun sorular olmadığını tespit etmişlerdir. Bu soruların çoğunlukla 2, 3 ve 4 . seviyelerde olduğu bunun yanında üst seviye olan 5 . seviyede 1 tane soru, 6 . seviyeden ise hiçbir soruya yer verilmediği bulunmuştur. Oysa bu tür sınavlarda da uluslararası sınavlarda olduğu gibi farklı seviyelerdeki sorulara yer verilebilir. Diğer taraftan Şaban (2019), PISA matematik yeterlilik düzeylerine göre ders kitaplarını cebir öğrenme alanına göre incelediğinde de en çok 2 . düzeydeki sorulara ağırlık verildiğini, üst düzeydeki sorulara yer verilmediğini tespit etmiştir. Bu çalışma öğrenme alanı üzerinde yapılan bir çalışma olması ve cebir öğrenme alanında üst düzeydeki sorulara yer verilmemesi ayn zamanda alt seviyedeki sorulara kitapta ağırlık verilmesi ile bu çalışma ile benzerlik göstermektedir. Yapılan bu araştırmalar ışığında incelenen farklı seviye düzeylerinde üst düzey sorulara yer verilmediği dikkat çekmiştir. İşte bu doğrultuda öğrencilerin başarısını artırmak amaçlı öğrencilerin kullandığı ders kitaplarında becerileri geliştirecek üst düzey sorulara yer verilmesi ile başlanabilir.

Araştırma sonuçlarından yola çıarak matematik ders kitabında bulunan soruların PISA uygulamasının sınavlarında yer verilen sorulardan oluşacak şekilde hazırlanması gerektiği anlaşılmaktadır. Başka bir sonuç, daha çok alt düzey olarak nitelenen 0 ve 1 . seviye sorulara yer verilmiş olmasıdır. Bu eksikliği giderebilmek için ders kitaplarında bulunan soruların kalitesi arttırılmalıdır.

Araştırmacılara, "PISA temel matematiksel becerileri 5 öğrenme alanı altına nasıl yerleştirilmeli ve bu beceriler öğrenme alanlarına göre farklılık oluşturabilir mi?" sorularına yönelik çalışmalar yapmaları önerilebilir.

\section{Kaynakça}

Altun, M. ve Arslan, Ç. (2006). İlköğretim öğrencilerinin problem çözme stratejilerini öğrenmeleri üzerine bir çalışma. Uludağ Üniversitesi Eğitim Fakültesi Dergisi, 19(1), 1-21.

Arslan, S. ve Özpınar, İ. (2009a). İlköğretim 6. sınıf matematik ders kitaplarının öğretmen görüşleri doğrultusunda değerlendirilmesi. Dicle Üniversitesi Ziya Gökalp Eğitim Fakültesi Dergisi, 12, 97-113.

Arslan, S. ve Özpınar, İ. (2009b). Yeni ilköğretim 6. sınıf matematik ders kitaplarının öğretim programına uygunluğunun incelenmesi. Çukurova Üniversitesi Eğitim Fakültesi Dergisi, 3(36), 26-38.

Çakır, A. (2006). İlköğretim dördüncü sinıf matematik ders kitaplarn ile ilgili öğretmen görüşleri. (Yüksek Lisans Tezi), Osmangazi Üniversitesi, Sosyal Bilimler Enstitüsü, Eskişehir.

Dane, A., Doğar, Ç. ve Balkı, N. (2004). İlköğretim 7. sınıf matematik ders kitaplarının değerlendirmesi. Erzincan Eğitim Fakültesi Dergisi, 6(2), 1-18.

Dede, Y. ve Yaman, S. (2005). İlköğretim 6., 7. ve 8. sinıf matematik ve fen bilgisi ders kitaplarının incelenmesi: Problem çözme ve problem kurma etkinlikleri bakımından. XIV. Ulusal Eğitim Bilimleri Kongresi, Pamukkale Üniversitesi Eğitim Fakültesi, Denizli. 
Erdem, E. (2011). İlköğretim 7. sını öğrencilerinin matematiksel ve olasılıksal muhakeme becerilerinin incelenmesi. (Yüksek Lisans Tezi), Adıyaman Üniversitesi, Fen Bilimler Enstitüsü, Adıyaman.

Güder, Y. ve Tutak, T. (2012). İlköğretim 5. sınıf öğretmenlerinin matematik ders kitabı hakkındaki görüş ve düşünceleri. Dicle Üniversitesi Ziya Gökalp Eğitim Fakültesi Dergisi, 19, 16-28.

Gürbüz, R. (2007). Olasılık konusunda geliştirilen materyallere dayalı öğretime ilişkin öğretmen ve öğrenci görüşleri. Kastamonu Eğitim Dergisi, 15(1), 259270.

Gürbüz, M. Ç. (2014). PISA matematik okuryazarlı öğretiminin PISA sorusu yazma ve matematik okuryazarlık düzeyleri üzerine etkisi. (Yüksek Lisans Tezi), Eğitim Bilimleri Enstitüsü, Uludağ Üniversitesi, Bursa.

Incikabi, S. (2017). Çoklu temsiller ve matematik öğretimi: Ders kitapları üzerine bir inceleme. Cumhuriyet International Journal of Education, 6(1), 66-81. https://doi.org/10.30703/cije.321438

İskenderoğlu, T. ve Baki, A. (2011). İlköğretim 8. sınıf matematik ders kitabındaki soruların PISA matematik yeterlik düzeylerine göre siniflandırılması. Eğitim ve Bilim, 36(161),287-301.

İskenderoğlu, T. A., Erkan, İ. ve Serbest, A. (2013). 2008-2013 y1lları arasındaki SBS matematik sorularının PISA matematik yeterlik düzeylerine göre sinıflandırılması. Turkish Journal of Computer and Mathematics Education, 4(2), 147-168.

Memnun, D. S. (2008). Olasılık kavramlarının öğrenilmesinde karşılaşılan zorluklar, bu kavramların öğrenilememe nedenleri ve çözüm önerileri. İnönü Üniversitesi Eğitim Fakültesi Dergisi, 9(15), 89-101.

Milli Eğitim Bakanlığı (MEB). (2012). PISA 2012 Türkıye ön raporu. Ankara: MEB. Millî Eğitim Bakanlığ1 (MEB). (2013). Ortaokul matematik dersi (5, 6, 7. ve 8. stmıflar) ögretim programı. Ankara: MEB.

Milli Eğitim Bakanlığı (MEB). (2018a). PISA 2018 Türkıye ön raporu. Ankara: MEB. Milli Eğitim Bakanlığ1 (MEB). (2018b). Illkokul ve ortaokul matematik dersi (1-8. sinıflar) ögrretim programı ve kılavuzu. Ankara: MEB.

Olkun, S. ve Toluk, Z. (2003). İlköğretimde etkinlik temelli matematik öğretimi. Ankara: Anı Yayıncilik .

Özsoy, H. (2007). İlköğretim 4-5. sinıf fen ve teknoloji ders kitaplarının öğrenci, öğretmen ve veli görüşleri bağlamında değerlendirilmesi. (Yüksek Lisans Tezi), Zonguldak Karaelmas Üniversitesi, Sosyal Bilimler Enstitüsü, Zonguldak.

Sáenz, C. (2009). The role of contextual, conceptual and procedural knowledge in activating mathematical competencies (PISA). Educational Studies in Mathematics, 71(2), 123-143. https:/ / doi.org/10.1007/s10649-008-9167-8

Savran, N. Z. (2004). PISA Projesi'nin Türk eğitim sistemi açısından değerlendirilmesi. Türk Ĕ̆itim Bilimleri Dergisi, 2(4), 397-412.

Seven, S. (2001). İlköğretim sosyal bilgiler ders kitapları hakkında öğretmen ve öğrenci görüşleri. (Yayınlanmamış Yüksek Lisans Tezi), Celal Bayar Üniversitesi, Sosyal Bilimler Enstitüsü, Manisa.

Sevimli, E. ve Kul, Ü. (2015). Matematik ders kitabı içeriklerinin teknolojik uygunluk açısından değerlendirilmesi: Ortaokul örneği. Necatibey Eğitim Fakültesi 
Elektronik Fen ve Matematik Eğitimi Dergisi, 9(1), 308-331. doi: 10.17522/nefefmed.11253

Soytürk, İ. (2011). Sınıf öğretmeni adaylarının matematik okuryazarlı̆̆ı öz-yeterlikleri ve matematiksel problem çözmeye yönelik inançlarının araştırılması. (Yüksek Lisans Tezi), İstanbul Üniversitesi, Sosyal Bilimler Enstitüsü, İstanbul.

Şaban, İ. H. (2019) Matematik ders kitapları cebir öğrenme alanındaki soruların PISA matematik yeterlik düzeylerine göre incelenmesi. (Yüksek Lisans Tezi), Hacettepe Üniversitesi, Eğitim Bilimleri Enstitüsü, Ankara.

Şener, Z. T. ve Bulut, N. (2015). 8. sinıf öğrencilerinin matematik derslerinde problem çözme sürecinde karşılaştıkları güçlükler. Gazi Üniversitesi Gazi Eğitim Fakültesi Dergisi, 35(3), 637-661.

Şişman, G. T., ve Akkaya, G. (2017). Ortaöğretim dokuzuncu sınıf matematik ders kitaplarının öğretim programına uygunluğu açısından incelenmesi. Pamukkale Üniversitesi Ĕ̆itim Fakültesi Dergisi, 42(42), 1-14. https://doi.org/10.9779/PUJE806

Turner, R., Blum, W. ve Niss, M .(2015). Assessing mathematical literacy: The PISA experience. In Stacey K and Turner R (Ed.), Using competencies to explain mathematical item demand: A work in progress (85-116). New York: Springer. https://doi.org/10.1007/978-3-319-10121-7_4

Umay, A. (2003). Matematiksel muhakeme yeteneği. Hacettepe Üniversitesi Ĕ̆itim Fakültesi Dergisi, 24(24), 234-243.

Yıldız, A. ve Baltacı, S. (2015). İlköğretim matematik öğretmen adaylarının problem kurma etkinlikleri ile olasılığa yönelik bilgilerinin incelenmesi. Ahi Evran Üniversitesi Kırşehir Eğitim Fakültesi Dergisi (KEFAD), 16(1), 201-213. https://doi.org/10.21764/efd.75669

Yıldız, A. ve Baltacı, S. (2016). İlköğretim matematik öğretmen adaylarının geometrik olasılık problemlerini çözme süreçlerinin analitik düşünme bağlamında incelenmesi. Mehmet Akif Ersoy Üniversitesi Ĕ̆itim Fakültesi Dergisi, 39, 91-111. https:// doi.org/10.21764/efd.75669

Yılmaz, E. T. (2006). Uluslararası öğrenci başarı değerlendirme programı (PISA)'nda Türkiye'deki öğrencilerin matematik başarıların etkileyen faktörler. (Yayımlanmamış Yüksek Lisans Tezi), Hacettepe Üniversitesi, Sosyal Bilimler Enstitüsü, Ankara.

\section{Summary}

\section{Introduction}

Programme for International Student Assessment (PISA) Test was first conducted in 2000 and Turkey first participated in this test, which is conducted in every three years, in 2003. However, it can be asserted Turkey could not achieve the desired success in mathematics. With the effects of these results, there have been considerable changes in approach to education, mathematics and mathematicseducation in recent years (Soytürk, 2011). Thus, it can be stated that some steps, which aim to have positive outcomes from studies regarding including basic mathematical skills in commonly used course books along with gaining and 
improving these skills, will occur. Looking through the studies in our country, it is seen that teachers' opinions have been received regarding the course books (Arslan and Özpınar, 2009a; Çakır, 2006; Güder ve Tutak, 2012), teachers' and students' opinions have been received (Seven, 2011) and in addition to teachers' and students' views, parents' views have been received about course books (Özsoy, 2007). However, it will be possible to see how PISA basic mathematical skills levels are included in $8^{\text {th }}$ grade mathematics course books thanks to this research. Therefore, the aim of this research, it is to analyze the distributions of PISA basic mathematical skills levels (communication, devising strategies, representation, using symbols, reasoning and argumentation, and mathematizing) on the questions in one of the prevailing $8^{\text {th }}$ Grade mathematics course books. In this regard, the research is important in terms of improving mathematics course books which are used effectively in schools.

\section{Method}

Document review was used in this research. $8^{\text {th }}$ grade mathematics course book was analyzed in detail by document analysis in terms of PISA basic mathematical skills. In order to analyze the questions, the course book was studied in two sections: content, assessment and evaluation. In this regard, the resource which was subjected to document review is one of the Ministry of National Education $8^{\text {th }}$ grade mathematics course books which were used during 2017-2018 academic year. Published by a private publishing house, this course book was found appropriate by Ministry of National Education for five years since the year it was published. The skills in the book called "Assessing Mathematical Literacy" and the levels of these skills are based on during the stage of collecting data. Expected behaviors from students for each level of six skills were explained and these levels are between Level 0 and Level 3 (Turner, Blum and Niss, 2015). In other words, each skill is categorized between the Level 0 and Level 3 in the related theoretical framework. For instance; there are skill levels as follows: the representation skill, Level 0 he/she reads the values from simple representation, Level 1 - he/she can use a simple or ordinary representation demonstration in order to explain the relationships in the given situations can do comparison, can acquire data from the charts. The questions in the course book were addressed in this way. The subjects in the course book were divided according to learning domain in this process. After the analysis, findings were converted to table under five learning domains and level distribution percentages of each skill were stated there. Therefore, it can be regarded as a portrait of learning domains by determining the level each question which intersects each learning domain.

\section{Results and Discussion}

It was seen that low level questions were dominant in the results of this research. In similar literature research, İskenderoğlu and Baki (2011) had concluded in their study that Level 2 questions were dominant in $8^{\text {th }}$ grade mathematics course books according to mathematics competencies which were also mentioned in PISA 2003 reports. The results of this study can be interpreted that they have similarities with this research as $8^{\text {th }}$ grade mathematics course book include Level 2 questions 
predominantly with regard to levels. Because, in this study, Level 2 students are expected to be successful in situations which need to be able to deduce directly and do not require any other abilities. In other words, it is sufficient to be able to use just one demonstration along with being able to do unit operations and using formulas. Therefore, it can be interpreted that Level 2 skills in above mentioned study are equal to low level in the theoretical framework of this research.

It is seen that the course book analyzed in this research, compared to other mathematical skills, generally includes devising strategies skill Level 0, Level 1 and Level 2 except possibility learning domain. It is good for students that there are various questions in different levels for devising strategies skill in the course books. Thus, Altun and Arslan (2006) said that learning environments organized with the aim of teaching devising strategies are effective in teaching some devising strategies and there are positive improvements in the conducted tests.

\section{Pedagogical Implications}

As a result of the research, it was seen that low level questions of six skills, studied generally in learning domains, were included predominantly in the course book. It was realized that especially low level questions were dominant in possibility learning domain.

All in all, it was seen that different skills were dominant in some learning domain as a result of this research. Based on this, it can be suggested to researchers to study for these questions: "How should we place PISA basic mathematical skills under five learning domains?" and "Do these skills differentiate according to learning domains?".

\section{Araştırmanın Etik Taahhüt Metni}

Yapılan bu çalışmada bilimsel, etik ve alıntı kurallarına uyulduğu; toplanan veriler üzerinde herhangi bir tahrifatın yapılmadığı, karşılaşılacak tüm etik ihlallerde “Cumhuriyet Uluslararası Eğitim Dergisi ve Editörünün” hiçbir sorumluluğunun olmadığı, tüm sorumluluğun Sorumlu Yazara ait olduğu ve bu çalışmanın herhangi başka bir akademik yayın ortamına değerlendirme için gönderilmemiş olduğu sorumlu yazar tarafından taahhüt edilmiştir.

\section{Authors' Biodata/Yazar Bilgileri}

Betül ŞİRIN Zonguldak'ta Matematik Öğretmeni olarak çalışmaktadır.

Betül Şirin has been working as a Mathematics Teacher at Zonguldak.

Avni YILDIZ Zonguldak Bülent Ecevit Üniversitesi, Ereğli Eğitim Fakültesi, Matematik Eğitimi ABD’nda Doçent Doktor olarak çalışmaktadır.

Avni Yıldız has been working as Associate Prof. Dr. in Zonguldak Bülent Ecevit University, Eregli Faculty of Education, the Department of Mathematics Education. 